\title{
PENDISTRIBUSIAN PRODUK DENGAN VOGEL 'S APPROXIMATION METHOD (VAM) DAN MODIFIED DISTRIBUTION METHOD (MODI)
}

\author{
Tri Hernawati ${ }^{1)}$ dan Isnaniah Laili $\mathrm{K} \mathrm{S}^{2)}$ \\ ${ }^{1)}$ Dosen Universitas Islam Sumatera Utara Medan \\ ${ }^{2)}$ Dosen Univesitas Medan Area \\ Email : trihernawati@ymail.com
}

\begin{abstract}
The research is aimed at analyzing the implementation of distribution transportation method and finding out the saving of distribution transportation cost by using Vogel's Approximation Method and Modified Distribution Method (MODI). The research used Vogel's Approximation Method as the initial solution and Modified Distribution Method as the final solution to save distribution transportation cost. Implementation of combination, Vogel's Approximation Method and Modified Distribution Method is a system will be develop to find the results of calculation of the initial cost of distribution, a minimum cost distribution, and allocation of items to be distributed from the origin place to the destination place. Entry data by user is origin place (many place and name of place), destination place (many place and name of place), amount of supply from the each origin, amount of demand from the each destination, and distribution cost from the each origin to the each destination. The result of the research shows minimalizing total distribution cost about $10,7 \%$
\end{abstract}

Keywords: Distribution, Transportation, minimum cost

\section{A.Pendahuluan}

\section{Latar Belakang}

Pendistribusian hasil produksi dmerupakan salah satu hal pokok terutama demi keberhasilan dalam hal pemasaran. Dengan pendistribusian yang tepat maka konsumen akan mudah dalam mendapatkan produk yang dihasilkan perusahaan, hal itu dapat meningkatkan kepercayaan konsumen. Yang menjadi permasalahan pokok adalah bagaimana pendistribusian produk yang optimal Penelitian yang dilakukan pada perusahaan mebel CV Mandiri ini akan memberikan alternative solusi dengan menggunakan metode kuantitatif yaitu Metode Pendekatan Vogel (Vogel Approximation Method ) yang dapat digunakan unruk menyelesaikan solusi awal pendisrtibusian produk dan dilanjutkan dengan Metode MODI (Modified Distriburion Method untuk menentukan solusi optimal.

\section{Distribusi dan Saluran Distribusi}

Menurut Tjiptono (1997) pendistribusian dapat diartikan sebagai kegiatan pemasaran yang berusaha memperlancar dan mempermudah penyampaian barang dan jasa dari produsen kepada konsumen, sehingga penggunaannya sesuai dengan yang diperlukan (jenis, jumlah, harga, tempat, dan saat dibutuhkan). Dengan kata lain, proses pendistribusian merupakan aktivitas pemasaran yang mampu: 
a. Menciptakan nilai tambah produk melalui fungsi-fungsi pemasaran yang merealisasikn kegunaan/utilitas bentuk, tempat, waktu, dan kepemilikan.

b. Memperlancar arus saluran pemasaran (marketing channel flow) secara fisik dan non-fisik. Yang dimaksud dengan arus pemasaran adalah aliran kegiatan yang terjadi diantara lembaga-lembaga pemasaran yang terlibat dalam proses pemasaran. Arus pemasaran tersebut meliputi arus barang fisik, arus kepemilikan, arus informasi, arus promosi, arus negosiasi, arus pembayaran, arus pendanaan, arus penanggunan resiko, dan arus pemesanan.

Dalam menciptakan kedua faedah tersebut, terdapat dua aspek penting yang terlibat didalamnya,yaitu:

- Lembaga yang berfungsi sebagai saluran distribusi (Channel of distribution/marketing channel).

- Aktivitas yang menyalurkan arus fisik barang (Physical distribution) Saluran distribusi adalah lembaga-lembaga distributor atau lembaga-lembaga penyalur yang mempunyai kegiatan untuk menyalurkan atau menyampaikan barang/jasa dari produsen hingga sampai ke konsumen akhir atau rute/rangkaian perantara baik yang dikelola pemasar maupun yang independen dalam menyampaikan barang dari produsen ke konsumen.

\section{Transportasi}

Masalah transportasi (transportation problem) pada umumnya berhubungan dengan distribusi suatu produk atau komoditi dari sumber tertentu ke lokasi tujuan dengan total biaya minimum. Metode transportasi merupakan bagian dari program linier. Taha (1982)dan Libermen (1994) mendefinisikan bahwa metode transportasi merupakan bentuk khusus dari pemprograman linier. Metode ini digunakan dalam mendistribusikan suatu barang dari daerah penghasil (produsen) ke sejumlah daerah tujuan agar biaya (pengorbanan) yang dikeluarkan menjadi minimum.

Masalah ini sering muncul dalam kehidupan sehari-hari merupakan salah satu kelas program linier (linier programming). Karena itu cara umum penyelesaian persoalan program linier seperti cara simpleks dapat digunakan unttuk menyelesaikan persoaloan ini. Tetapi karena penampilan yang khusus diperlukan cara-cara penyelesaian yang lebih praktis dan efisien.

Contoh tabel persoalan transportasi 3 sumber dan 3 tujuan $(m-=3, n=3)$ dapat dilihat pada tabel 1

Hal yang merupakan ciri transportasi yaitu menyangkut sejenis produk tertentu.

\section{Formulasi Model Transportasi}

Misalkan ada $\mathrm{m}$ sumber dan $\mathrm{n}$ tujuan. Masing-masing sumber mempunyai kapasitas $\mathrm{a}_{\mathrm{i}}(\mathrm{i}=$ $1,2, m) . M a s i n g$-masing tujuan membutuhkan komoditi sebanyak $b_{j}(j=1,2, \ldots n)$ Jumlah satuan (unit) yang dikirim dari sumber i ke tujuan $\mathrm{j}$ adalah sebanyak $\mathrm{X}_{\mathrm{ij} \text {. }}$ Ongkos pengiriman per unit dari sumber $\mathrm{i}$ ke tujuan $\mathrm{j}$ adalah $\mathrm{C}_{\mathrm{ij}}$ Formulasi model program linier dari persoalan transporasi tersebut adalah :

Fungsi tujuan :

Minimumkan $Z=\sum_{i=1}^{m} \sum_{j=1}^{n} C_{i j} X_{i j}$

Dengan batasan : 


$$
\begin{aligned}
& \sum_{j=1}^{n} X_{i j}=a_{i}(\mathrm{i}=1,2, \ldots . \mathrm{m}) \\
& \sum_{i=1}^{m} X_{i j}=b_{j}(\mathrm{j}=1,2, \ldots . . \mathrm{n}) \\
& \text { Xij } \geq 0 \text { (untuk seluruh } \mathrm{i} \text { dan } \mathrm{j})
\end{aligned}
$$

Tujuan dari persoalan transportasi adalah mencari suatu pola pengiriman yang optimal dengan meminimumkan jumlah ongkos transpotasi dari semua sumber i ke semua tujuan j.

Model persoalan transportasi dapat dilihat pada tabel 1.

Tabel 1. Model Transpotasi

\section{Formulasi model:}

Fungsi Tujuan :

Minimumkan :

$$
\mathrm{Z}=\mathrm{C}_{11} \mathrm{X}_{11}+\mathrm{C}_{12} \mathrm{X}_{12}+\mathrm{C}_{13} \mathrm{X}_{13}+\mathrm{C}_{21} \mathrm{X}_{21}+\mathrm{C}_{22} \mathrm{X}_{22}+\mathrm{C}_{23} \mathrm{X}_{23}+\mathrm{C}_{31} \mathrm{X}_{31}+\mathrm{C}_{32} \mathrm{X}_{32}+\mathrm{C}_{33} \mathrm{X}_{33}
$$

Fungsi Pembatas :

a. Pembatas sumber:

$$
\begin{aligned}
& X_{11}+X_{12}+X_{13}=a_{1} \\
& X_{21}+X_{22}+X_{23}=a_{2} \\
& X_{31}+X_{32}+X_{33}=a_{3}
\end{aligned}
$$

a. Pembatas tujuan :

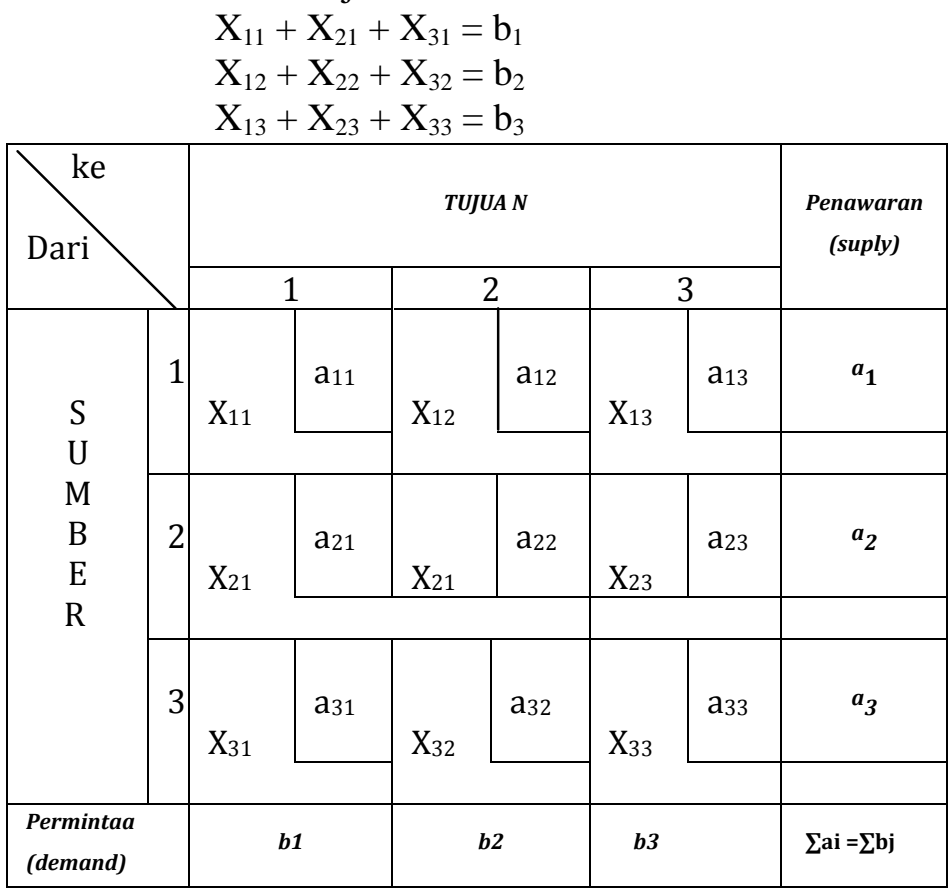

Pembatas non negatif

$$
X_{\mathrm{ij}} \geq 0
$$

Keseimbangan Transportasi

Suatu model transportasi dikatakan seimbang bila total suplai (yang tersedia pada sumber) sama dengan total permintaan pada tujuan, (Siagian, 1987),

atau :

$$
\begin{aligned}
& \mathrm{m} \\
& \sum \mathrm{a}_{\mathrm{i}}=\sum \mathrm{b}_{\mathrm{j}}
\end{aligned}
$$




$$
i=1 \quad j=1
$$

Dalam persoaloan yanag sebenarnya batasan ini tidak selalu terpenuhi, atau jumlah persediaan yang tersedia mungkin lebih besar atau lebih kecil dari pada jumlah yang diminta. Jika hal ini terjadi maka model persoalannya disebut sebagai model yang tidak seimbang. Seandainya yang dihadapi bukan persoalan seimbang, cara mengatasinya adalah dengan menambahkan sumber atau tujuan hayal (dummy).

a. Jiika jumlah suplai lebih besar dari permintaan maka tambahkan tujuan ke $(n+1)$ dengan permintaan sejumlah :

$$
b_{n+1}=\sum_{i=1}^{m} a_{i}-\sum_{j=1}^{n} b_{j}
$$

dan ongkos pengiriman $C_{i, n+i}=0$ untuk $i=1,2, \ldots m$ dalam hal ini $X_{i, n+i}$ merupakan suplai yang tidak digunakan.

b. Jika jumlah permintaan lebih besar dari suplai, maka tambahkan sumber tambahan ke $(m+1)$ dengan kapasitas sejumlah :

$$
\begin{aligned}
& \mathrm{n} m \\
& \mathrm{a}_{\mathrm{m}+1}=\sum \mathrm{b}_{\mathrm{j}}-\sum \mathrm{a}_{\mathrm{i}} \\
& j=1 \quad i=1
\end{aligned}
$$

dan ongkos pengiriman $\mathrm{C}_{\mathrm{m}+1, \mathrm{j}}=0$ untuk $\mathrm{j}=1,2, \ldots \mathrm{n}$

dimana $\mathrm{X}_{\mathrm{m}+1, \mathrm{i}}$ adalah jumlah kekurangan pada tujuan $\mathrm{j}$

\section{Metode Pemecahan}

Teknik yang digunakan pada dasarnya menggunakan metode simpleks, tetapi karena struktur matriksnya yang khas penyelesaiannya berbeda dengan simpleks.

Dari persoalan dengan $m$ sumber dan $n$ tujuan, akan diperoleh $(m+n)$ kendala dengan $m x n$ variabel. Tetapi dalam masalah transportasi variabel yang mempunyai nilai positip hanya $(\mathrm{m}+\mathrm{n}-1)$.

Langkah-langkah :

1. Menentukan solusi layak basis awal, dapat dilakukan dengan menggunakan salah satu dari metode pojok kiri atas (North West Corner Rule), metode ongkos terkecil (Least Cost) atau metode pendekatan VOGEL (VOGEL's Aproximation Method).

2. Menentukan solusi optimal

a. Menentukan entering variabel (variabel bukan basis yang akan menjadi basis) dari variabel-variabel bukan basis. Bila semua variabel sudah memenuhi kondisi optimal, maka langkah pengerjaan dihentikan bila belum dilanjutkan ke langkah b,

b. Menentukan living variabel (variabel basis yang akan meninggalkan basis) diantara variabel basis yang ada, kemudian menghitung solusi yang baru. Selanjutnya kembali langkah a

Langkah a dan b dapat dilakukan dengan salah metode, yaitu MODI (Modified Distribution Method), metode U-V atau metode batu loncatan (Stepping Stone).

\section{Menentukan Solusi Layak Basis Awal}

\section{Metode Pojok Kiri Atas (North West Corner Rule)}

a. Metode pojok kiri atas adalah metode yang paling sederhana diantara metode lainnya. Langkah-langla penyelesaiannya adalah Dimulai pada pojok kiri atas tabel dan dialokasikan sebanyak mungkin pada $\mathrm{X}_{11}$ tanpa menyimpang dari kendala suplai dan permintaan. 
b. Bergerak ke kotak (sel) sebelah kanan apabila terdapat suplai yang cukup, apabila tidak cukup bergeraklah ke kotrak dibaweahnya.

c. Lanjutkan dengan cara yang sama sampai suplai telah habis dan keperluan permintaan telah dipenuhi.

Jawab layak basis yang ditemukan dengan menggunakan pojok kori atas, mungkin masih jauh dari optimal karena ongkos transpor sama sekali tidak diikutsertakan dalam perhitungan. Meskipun demikian cara ini masih lebih baik dibandingkan dengan cara simpleks .

\section{Metode Biaya Terkecil (Least Cost Method)}

Metode biaya terkecil berusaha mencapai tujuan minimisasi biaya transportasi dengan alokasi terhadap sel sesuai dengan besarnya biaya transportasi per unit produk (komoditi) Langkah-langkah penyelesaian sbb :

a. Pilih variabel $\mathrm{Xj}$ (sel) yang memiliki biaya transpor (Cij) terkecil dan alokasikan sebanyak mungkin dengan syarat batasan suplai dan permintaan dipenuhi.

b. Dari sel sisanya yang layak (yang tidak terisi atau tidak dihilangkan) pilih nilai Cij terkecil dan alokasikan sebanyak mungkin .

c. Ulangi langkah diatas sampai semuanya teralokasi.

\section{Metode Pendekatan Vogel (Vogel's Approximation Method)}

Metode Vogel selalu memberikan solusi awal yang lebih baik dibandingkan dengan metode lainnya. Kenyataannya pada beberapa kasus solousi awal yang diperoleh melalui metode vogel akan mencapai optimum.

Langkah-langkah penyelesaian dengan metode Vogel :

a. Hitung perbedaan dua ongkos yang paling kecil untuk setiap baris dan kolom

b. Pilih kolom atau baris yang mempunyai perbedaan ongkos paling besar

c. Tempatkan kemungkinan alokasi yang paling besar pada ongkos yang paling kecil dengan batasan jumlah suplai dan permintaan

d. Ulangi langkah diatas sampai seluruhnya teralokasi.

\section{Menentukan Solusi Optimal}

\section{Metode MODI (Metode U-V)}

Setelah solusi layak awal dasar diperoleh, kemudian dilakukan perhitungan untuk mencapai solusi optimal.Salah satu metode yang dapat digunakan adalah metode MODI. MODI adalah singkatan dari Modified Distribution.

Di dalam metode ini dihitung nilai Ui dan $\mathrm{Vj}$.

- Untuk setiap basic variable berlaku $\mathrm{Ui}+\mathrm{Vj}=\mathrm{Cij}$.

Misalkan $\mathrm{U}_{1}$ atau $\mathrm{V}_{1}$ sama dengan 0 (nol)

- Untuk non Basic variable berlaku Cij' $=\mathrm{Clj}-\mathrm{Ui}-\mathrm{Vj}$

Bila Cij' $\geq 0$ maka diperoleh penyelesaian opimal.

Langkah-langkah penggunaan metode MODI ádalah sbb :

a. Untuk setiap tabel pemecahan awal, dihitung nilai $\mathrm{Ui}$ dan $\mathrm{Vj}$ dengan formula : $\mathrm{Cij}=\mathrm{Ui}+\mathrm{Vj}$ misalkan $\mathrm{U}_{1}$ atau $\mathrm{V}_{1}=0$

b. Hitung perubahan biaya (Cij') untuk setiap variable non basis dengan formula: $\mathrm{Cij}^{\prime}=\mathrm{Cij}-\mathrm{Ui}-\mathrm{Vj}$

c.. Jika terdapat nilai Cij' negatif, maka solusi belum opimal. Pilih variable Xij dengan nilai Cij' negatif terbesar sebagai entering variable.

d Alokasikan produk ke entering variable (Xij)

e. Hitung kembali nilai Cij. Jika semua nilai sudah positiup berarti solusi sudah optimal. Jika tidak kembali ke langkah a. 


\section{Metode Batu Loncatan (Stepping Stone)}

Berdasarkan solusi persoalan transpor dengan melakukan perbaikan bertingkat dari solusi awal yang telah disusun. Untuk menentukan entering dan living variabel terlebih harus dahulu dibuat loop tertutup bagi setiap variable non basis. Loop tersebut berawal dan berakhir pada variable non basis tadi.

Caranya carilah nilai Cij'tiap-tiap sel non basis. Cij' yang merupakan negatif terbesar akan masuk menggantikan sel basis. Bila telah diperoleh Cij' $\geq 0$, maka penyelesaian sudah optimal. Masalah utama dalam metode ini ialah mencari loop (lingkaran evaluasi) bagi setiap sel non basis. Suatu hal yang perlu diperhatikan ialah sel-sel yang terdapt dalam lingkaran evaluasi sepasang-sepasang berada dalam baris atau kolom yang sama.

Beberapa hal penting yang perlu diperhatikan dalam proses penyusunan jalur stepping stone :

a. Arah yang diambil baik searah maupun berlawanan arah dengan arah jarum jam adalah tidak penting dalam membuat jalur tertutup

b. Hanya ada satu jalur tertutup untuk setiap kotak kosong

c. Jalur harus mengikuti kotak terisi kecuali kotak kosong yang sedang dievaluasi

d. Adanya penambahan dan pengurangan yang sama besar harus kelihatan pada setiap baris dan kolom dalam jalur.

\section{Metologi}

Langkah-langkah pemecahan masalah pendistribusian dalam penelitian ini dapat dilihat pada gambar 1

\section{Pengumpulan Data}

Data yang dibutuhkan dalah data jumlah produk yang dikirim dari sumber ke lokasi tujuan. Dalam hal ini perusahaan mempunyai gudang sebagai simber yang terdapat di empat lokasi.

Data lokasi sumber serta jumlah produk yang akan dikirimkan ke lokasi tujuan dapat dilihat pada tabel 2.

Tabel 2 Jumlah Suplay Setiap Gudang (unit)

\begin{tabular}{|l|l|c|}
\hline No & Gudang & $\begin{array}{c}\text { Suplay Bulanan } \\
\text { (unit) }\end{array}$ \\
\hline 1 & Tebing Tinggi & 190 \\
\hline 2 & Kuala Tanjung & 170 \\
\hline 3 & Siborong borong & 170 \\
\hline 4 & Dumai & 350 \\
\hline
\end{tabular}

Jumlah demand pada masing=masing lokasi tujuan dapat dilihat pada tabel 3 .

Biaya transportasi/ unit dari masing-masing lokasi tujuan dapat dilihat pada tabel 4.

Jalur distribusi sebelum dilakukan penditribusian menurut metode Vogel- Modi dapat dilihat pada tabel 5 
ISSN : 2407-2648

Gbr.1 Metodologi Penelitian

\section{Hasil dan Pembahasan}

Palam penelitian ini untuk memecahkan masalah transportasi, dimulai dengan menentukan solusi awal (initial solution) yang dapat dilihat pada table7. Pada table 7 dapat dilihat bahwa jumlah suplai tidak sama dengan demand, maka perlu ditambahkan kolom dummy. Kemudian dilanjutkan dengan pengujian optimalisasi solusi awal tersebut. Dalam menentukan solusi awal yang fisibel dapat digunakan beberapa metode transportasi .Namun pada penelitian ini penulis menggunakan metode VAM dan dilanutkan dengan solusi optimal dengan metode MODI karena metode ini merupakan metode transportasi yang menghasilkan solusi yang optimum dan merupakan metode yang paling baik digunakan daripada metode lainnya karena lebih mudah dan lebih cepat dalam mengatur alokasi dari beberapa sumber ke beberapa daerah tujuan . Kegiatan pendistribusian yang dilakukan prusahaan selama ini mengeluarkan biaya sebesar Rp 3.479.400, Ternyata dengan menggunakan metode transportasi yang diusulkan menyebabkan pola pengalokasian berubah dan pelaksanaan pendistribusian produk hanya mengeluarkan biaya sebesar Rp 3.107.000 sehingga terjadi selisih atau penghematan biaya sebesar Rp 372.400 atau dengan kata lain telah terjadi pengurangan biaya atau efisiensi biaya distribusi sebesar $10,7 \%$

\section{KESIMPULAN DAN SARAN}

Berdasarkan hasil perhitungan yang telah dilakukan ternyata pendistribusian yang dilakukan lebih baik dari pada selama ini yang dilakukan pertusahaan, karena 
pendistribusian dengan menggunakan metode ini dapat meminimisasi biaya sebesar 10,7 $\%$. Sehingga penggunaan metode transportasi dengan solusi awal VAM (Vogel's Approximation Method) dan pengujian optimalisasi menggunakan metode MODI (The Modified Distribution Method) lebih efektif dalam upaya meningkatkan efisiensi biaya distribusi dari pada menggunakan sistem yang digunakan selama ini.

Sehingga peneliti menyarankan kepada perusahaan untuk mencoba mengaplikasikan merode tersebut dalam pendistribusian produknya.

\section{DAFTAR PUSTAKA}

[1].Hiller FrederickS,GeraldJ.Lieberman.1994.Pengantar Riset Operasi ， Erlangga, Jakarta.

[2]SiagianP.,1987.Penelitian Operasional Teori dan Praktek,Universitas Indonesia Press, Jakarta

[3].Taha Hamdy A.,1982.,Operation Research an Introduction Third Edition , MacMillan., Inc, New York, USA

[4].Tjiptono, Fandy, 1997. Strategi Pemasaran,Penerbit ANDI, Yogyakarta. 
Tabel 3. Jumlah produk yang dibutuhkan (demand) masing-masing sumber

\begin{tabular}{|l|l|c|c|}
\hline No & Pasar & $\begin{array}{c}\text { Penjualan } \\
\text { (\%) }\end{array}$ & $\begin{array}{c}\text { Demand } \\
\text { (unit) }\end{array}$ \\
\hline 1 & Tebing Tinggi & 8,3 & 71 \\
\hline 2 & Dolok & 5,7 & 49 \\
\hline 3 & Sei Langge & 6,3 & 54 \\
\hline 4 & Kuala Tanjung & 7,4 & 63 \\
\hline 5 & Kisaran & 3,6 & 31 \\
\hline 6 & Batu Bara & 8,5 & 73 \\
\hline 7 & Siborong - borong & 6,5 & 55 \\
\hline 8 & Gunung Tua & 12,6 & 108 \\
\hline 9 & Dumai & 28,4 & 243 \\
\hline 10 & Kota Pinang & 12,7 & 108 \\
\hline & Total & $100(\%)$ & 855 \\
\hline
\end{tabular}

Tabel 4. Biaya Transportasi dari Lokasi Sumber ke Lokasi Tujuan (Ribuan rupiah)

\begin{tabular}{|l|c|c|c|c|c|c|c|c|c|c|}
\hline $\begin{array}{l}\text { Pasar } \\
\text { Gudang }\end{array}$ & $\begin{array}{c}\text { Tebing } \\
\text { Tinggi }\end{array}$ & Dolok & $\begin{array}{c}\text { Sei } \\
\text { Langge }\end{array}$ & $\begin{array}{c}\text { Kuala } \\
\text { Tanjung }\end{array}$ & Kisaran & $\begin{array}{c}\text { Batu } \\
\text { Bara }\end{array}$ & $\begin{array}{c}\text { Siborong } \\
\text { borong }\end{array}$ & $\begin{array}{c}\text { Gunung } \\
\text { Tua }\end{array}$ & Dumai & $\begin{array}{c}\text { Kota } \\
\text { Pinang }\end{array}$ \\
\hline $\begin{array}{l}\text { Tebing } \\
\text { Tinggi }\end{array}$ & - & 66 & 48 & 66 & 164 & 128 & 2740 & 2740 & 520 & 160 \\
\hline $\begin{array}{l}\text { Kuala } \\
\text { Tanjung }\end{array}$ & 66 & 54 & 42 & - & 40 & 46 & 1880 & 980 & 470 & 124 \\
\hline $\begin{array}{l}\text { Siborong } \\
\text {-borong }\end{array}$ & 274 & 186 & 168 & 188 & 96 & 136 & - & 440 & 174 & 58 \\
\hline Dumai & 520 & 460 & 420 & 470 & 194 & 192 & 1740 & 1600 & - & 120 \\
\hline
\end{tabular}


Tabel 5. Pendistribusian Produk menurut Perusahaan

\begin{tabular}{|c|l|l|c|c|c|}
\hline No & Gudang & Pasar & Demand & $\begin{array}{c}\text { Biaya } \\
\text { Transportasi } \\
\text { (Rp./unit) }\end{array}$ & $\begin{array}{c}\text { Total Biaya } \\
\text { Transportasi } \\
\text { (Rp.) }\end{array}$ \\
\hline 1 & Tebing Tinggi & Tebing Tinggi & 71 & 0 & 0 \\
\hline & & Dolok & 49 & 6.600 & 323.400 \\
\hline & & Sei Langge & 54 & 4.800 & 259.200 \\
\hline & & Gunung Tua & 16 & 27.400 & 438.400 \\
\hline 2 & Kuala Tanjung & Kuala Tanjung & 63 & 0 & 0 \\
\hline & & Kisaran & 31 & 4.000 & 124.000 \\
\hline & & Batubara & 73 & 4.600 & 335.800 \\
\hline 3 & $\begin{array}{l}\text { Siborong- } \\
\text { borong }\end{array}$ & Gunung Tua & 3 & 9.800 & 29.400 \\
\hline & & Siborong- & 55 & 0 & 0 \\
\hline & & Gorong & 7 & 4.400 & 30.800 \\
\hline 4 & Dunung Tua & Kota Pinang & 108 & 5.800 & 626.400 \\
\hline & & Gunung Tua & 82 & 16.000 & 1.312 .000 \\
\hline & & Dumai & 243 & 0 & 0 \\
\hline
\end{tabular}

Tabel 6. Distribusi Produk Optimal

\begin{tabular}{|c|l|l|c|c|c|}
\hline No & Gudang & Pasar & Demand & $\begin{array}{c}\text { Biaya } \\
\text { Transportasi } \\
\text { (Rp./unit) }\end{array}$ & $\begin{array}{c}\text { Total Biaya } \\
\text { Transportasi } \\
\text { (Rp.) }\end{array}$ \\
\hline 1 & Tebing Tinggi & Tebing Tinggi & 71 & 0 & 0 \\
\hline & & Dolok & 49 & 6.600 & 323.400 \\
\hline & & Sei Langge & 54 & 4.800 & 259.200 \\
\hline & & $\begin{array}{l}\text { Siborong- } \\
\text { borong }\end{array}$ & 16 & 27.400 & 438.400 \\
\hline 2 & $\begin{array}{l}\text { Kuala } \\
\text { Tanjung }\end{array}$ & $\begin{array}{l}\text { Kuala } \\
\text { Tanjung }\end{array}$ & 63 & 0 & 0 \\
\hline & & Kisaran & 31 & 4.000 & 124.000 \\
\hline & & Batubara & 73 & 4.600 & 335.800 \\
\hline 3 & $\begin{array}{l}\text { Siborong- } \\
\text { borong }\end{array}$ & $\begin{array}{l}\text { Siborong- } \\
\text { borong }\end{array}$ & 3 & 9.800 & 29.400 \\
\hline & & Gunung Tua & 105 & 0 & 0 \\
\hline & & Kota Pinang & 26 & 5.400 & 462.000 \\
\hline 4 & Dumai & Dumai & 243 & 0 & 150.800 \\
\hline & \multicolumn{2}{|l}{ Total Biaya } & & 0 \\
\hline
\end{tabular}


ISSN : 2407-2648

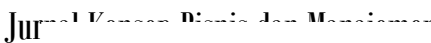

E-ISSN : 2497-263X

Tabel 7. Table Awal Pendistribusian Produk

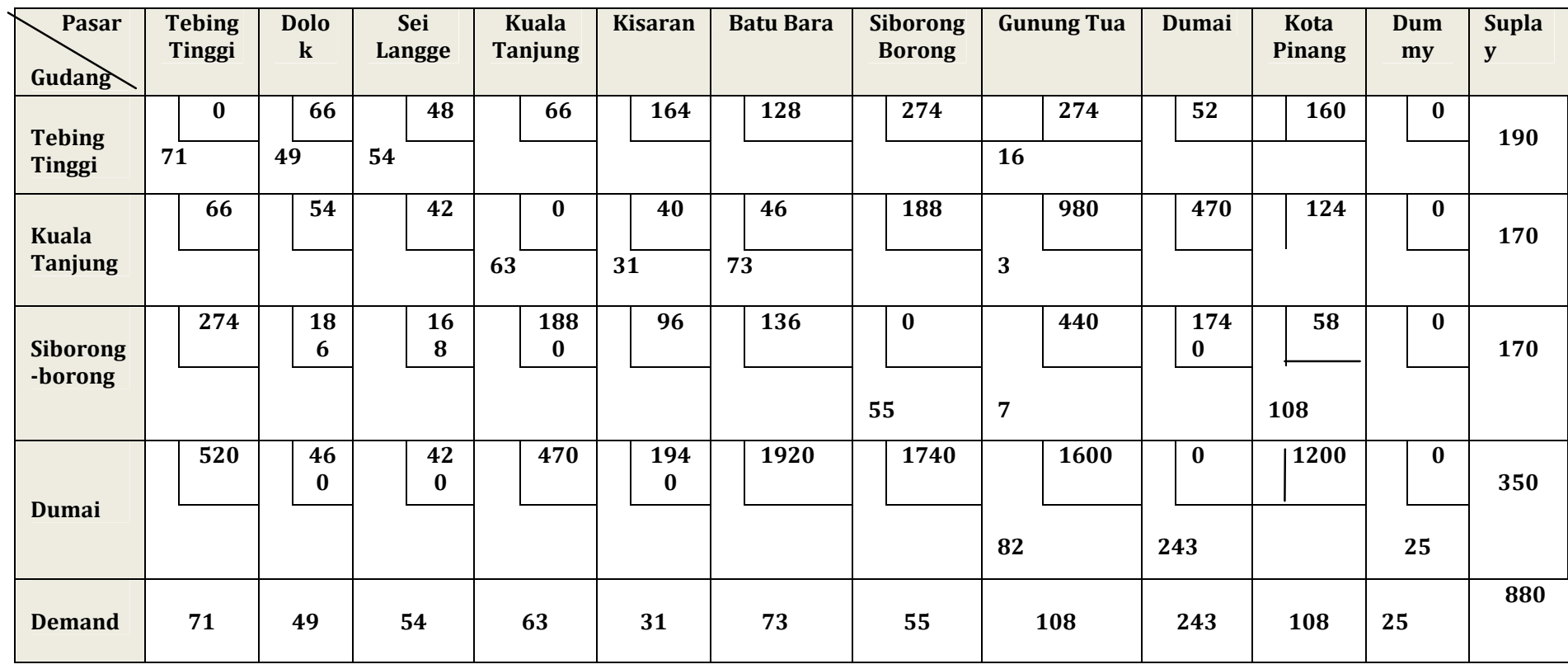

Tabel 8. Solusi Optimal Pendistribusian Produk

\begin{tabular}{|c|c|c|c|c|c|c|c|c|c|c|c|c|}
\hline Gudang & $\begin{array}{l}\text { Tebing } \\
\text { Tinggi }\end{array}$ & Dolok & $\begin{array}{c}\text { Sei } \\
\text { Langge }\end{array}$ & $\begin{array}{c}\text { Kuala } \\
\text { Tanjun } \\
\text { g }\end{array}$ & Kisaran & Batu Bara & $\begin{array}{c}\text { Siborong } \\
\text { Borong }\end{array}$ & Gunung Tua & Dumai & $\begin{array}{c}\text { Kota } \\
\text { Pinang }\end{array}$ & $\begin{array}{c}\text { Dum } \\
\text { my }\end{array}$ & Suplay \\
\hline $\begin{array}{l}\text { Tebing } \\
\text { Tinggi }\end{array}$ & \begin{tabular}{r|r} 
& 0 \\
71 & \\
\end{tabular} & \begin{tabular}{|r}
66 \\
49 \\
\end{tabular} & $\begin{array}{r}48 \\
54 \\
\end{array}$ & 66 & 164 & 128 & 274 & \begin{tabular}{|l}
274 \\
16 \\
\end{tabular} & 52 & 160 & $\mathbf{0}$ & 190 \\
\hline $\begin{array}{l}\text { Kuala } \\
\text { Tanjung }\end{array}$ & 66 & 54 & 42 & $\begin{array}{r}0 \\
63 \\
\end{array}$ & $\begin{array}{r}40 \\
31 \\
\end{array}$ & $\begin{array}{l}46 \\
73 \\
\end{array}$ & 188 & $\begin{array}{l}980 \\
3 \\
\end{array}$ & 470 & 124 & $\mathbf{0}$ & 170 \\
\hline $\begin{array}{l}\text { Siborong } \\
\text {-borong }\end{array}$ & 274 & 186 & 168 & $\begin{array}{c}188 \\
0\end{array}$ & 96 & 136 & $\begin{array}{l}\mathbf{0} \\
55\end{array}$ & $\begin{array}{l}440 \\
7\end{array}$ & $\begin{array}{l}174 \\
0\end{array}$ & \begin{tabular}{|r|}
58 \\
108
\end{tabular} & $\mathbf{0}$ & 170 \\
\hline Dumai & 520 & 460 & 420 & 470 & $\begin{array}{c}194 \\
0\end{array}$ & 1920 & 1740 & 1600 & \begin{tabular}{|c|}
0 \\
243
\end{tabular} & $\begin{array}{c}\begin{array}{c}120 \\
0\end{array} \\
82\end{array}$ & $\begin{array}{r}0 \\
25\end{array}$ & 350 \\
\hline Demand & 71 & 49 & 54 & 63 & 31 & 73 & 55 & 108 & 243 & 108 & 25 & 880 \\
\hline
\end{tabular}

